\title{
PEMANFAATAN BATANG PISANG (MUSA PARADISIACA L) DALAM PEMBUATAN PULP DENGAN MENGGUNAKAN METODE ACETOSOLV SERTA IMPLEMENTASINYA DI SEKOLAH
}

\author{
Afriati Fitri ${ }^{1)}$, Zona Octarya, M.Si ${ }^{1)}$ \\ ${ }^{1}$ Fakultas Tarbiyah dan Keguruan, Universitas Islam Negeri Sultan Syarif Kasim Riau \\ Email: souvenirznoc@yahoo.co.id
}

\begin{abstract}
Acetosolv process is one of making pulp alternative which friendly environmental. Making pulp of banana stem with a solution of acetic acid cooking $\left(\mathrm{CH}_{3} \mathrm{COOH}\right)$ and catalyst sulfate acid $\left(\mathrm{H}_{2} \mathrm{SO}_{4}\right)$ are expected to take place simultaneously, either delignification process or degradation of polisakarida. The variable process is looked in this research is concentration of acetic acid $(70 \%-$ $w t, 80 \%-w t$, 90-wt\%) with cooking time (1 hour, 2 hours, 3 hours), whereas constant variabel in this research in liquid to solid ratio (20/1), concentration catalyst $(0.6 \%$-wt), and measure of raw materials $( \pm 1,5 \mathrm{~cm})$. The result of the study exhibit banana stem may become as raw material in making pulp which using acetosolv. Yield pulp around $50.64 \%-57.13 \%$ with content of lignin pulp $12.5 \%-19.42 \%$, and content of cellulose pulp $80,85 \%-82,28 \%$, which is variation according to process. The best condition which produce yield with high cellulose level and low lignin are gotten at concentration of cooking 90\%-wt with time of cooking 3 hours. The result shows that banana stem pulp have yield of $50.64 \%$, lignin $12.5 \%$ and cellulose $87.49 \%$. Implementation knowledge of student senior high school 1 Tembilahan to exploiting banana stem in making pulp categorized as "very good" because the final results show the percentage obtained $86.78 \%$ which lies in the range of $81 \%-100 \%$, this percentage is in the category of "very good".
\end{abstract}

Keywords: Banana stem, Acetosolv, Yield pulp, Lignin, Cellulose, Implementation.

\section{PENDAHULUAN}

Kertas menjadi salah satu sarana komunikasi secara nonverbal dalam berbagai sektor kehidupan. Indonesia yang penduduknya berjumlah 237.556.363 (sensus tahun 2010, Badan Pusat Statistik) menjadikan negara tersebut komsumtif dalam pemakaian jumlah kertas, [1]. Pembuatan pulp dan kertas pada umumnya menggunakan kayu hutan sebagai bahan dasar pembuatannya. Eksploitasi hutan yang terus menerus menimbulkan banyak masalah terutama penggundulan hutan dan isu pemanasan global serta semakin menipisnya cadangan kayu. Maka pencarian bahan baku alternatif sangat dibutuhkan untuk mengurangi ketergantungan pada kayu sebagai bahan baku pulp dan kertas seperti batang pisang. Pohon pisang hanya dapat berbuah sekali, setelah itu pohon tersebut harus dibuang dan menjadi limbah berupa batang pisang. Tetapi sampai pada saat ini batang pisang tidak dimanfaatkan sebaik mungkin. Setelah panen buah, batang pisang masih dibiarkan tertinggal dan akan menjadi limbah baru. Padahal jika dilihat dari kandungannya, batang pisang memiliki karakteristik serat yang baik, sehingga berpotensi untuk digunakan sebagai bahan baku pembuatan pulp.

Allah telah berfirman dalam al-Qur'an agar manusia memperhatikan lingkungan sekitar untuk diambil manfaatnya, sebagaimana yang terkandung dalam Surah Yunus ayat 101 yang artinya "Katakanlah, "perhatikanlah apa yang ada di langit dan dibumi!" Tidaklah bermanfaat tandatanda (kebesaran Allah) dan rasul-rasul yang memberi peringatan bagi orang yang tidak beriman". Dengan mengambil hikmah dari ayat ini, salah satu upaya memanfaatkan tanda-tanda kebesaran Allah adalah dengan memanfaatkan limbah batang pisang, hal ini menjelaskan bahwa segala sesuatu yang Allah ciptakan selalu memberikan manfaat bagi manusia yang berakal.

Seiring dengan bertambahnya ilmu pengetahuan dan teknologi tanaman pisang yang dibudidayakan secara intensif dengan menerapkan teknologi yang benar dapat memberikan keuntungan yang tinggi dan mampu bersaing dengan tanaman yang lain menambah nilai ekonomi dari limbah tersebut, [2]. Salah satu cara pengolahannya yang dapat memanfaatkan keseluruhan 
komponen biomassa dan ramah lingkungan adalah metode fraksionasi menggunakan pelarut-pelarut organik (organosolv process).

Pengolahan biomassa secara fraksionasi dengan menggunakan pelarut organik didasarkan pada perbedaan sifat kimia-fisik dari komponen penyusunnya. Metode fraksionasi biomassa dengan pelarut organik telah banyak dikembangkan karena memiliki beberapa keunggulan yaitu tidak menggunakan unsur belerang dalam produksinya sehingga tidak menimbulkan odour problem, daur ulang bahan kimia dapat dilakukan dengan cara yang sangat sederhana dan dapat menghasilkan produk samping (by-products), [3]. Salah satu pelarut organik yang banyak diminati adalah asam asetat (acetosolv process) karena prosesnya dapat dilangsungkan pada temperatur dan tekanan rendah maupun tinggi, harganya relatif murah, serta dapat dikerjakan tanpa atau dengan bantuan katalis. Penggunaan asam asetat sebagai media fraksionasi biomassa mampu memisahkan secara selektif komponenkomponen penyusun biomassa. Selainmempertimbangkan kemudahan cara pengolahan pembuatan pulp, pemilihan metode acetosolv bisa dengan mudah diimplementasikan di sekolah. Tujuan pengimplementasiannya untuk mengetahui tingkat pengetahuan siswa terhadap pengolahan pulp dengan menggunakan metode acetosolv.

\section{METODE PENELITIAN}

\section{Tempat dan Waktu Penelitian}

Penelitian ini dilaksanakan di Laboraturium Patologi, Entomologi dan Mikrobiologi Fakultas Pertanian dan Perternakan UIN SUSKA RIAU dan SMAN 1 Tembilahan. Waktu penelitian ini dimulai dari bulan April sampai dengan bulan Mei 2014.

\section{Alat dan bahan}

Alat: hot plate, erlenmeyer $250 \mathrm{ml}$ dan $1000 \mathrm{ml}$, gelas kimia, oven, neraca analisis, kertas saring, spatula dan aluminium foil. Bahan: batang pisang, Asam asetat konsentrasi $70 \%$, 80\% dan 90\%, Asam sulfat $0,6 \%$ dan aquades.

\section{Prosedur Penelitian}

\section{1) Perlakuan terhadap batang pisang}

Batang pisang yang digunakan pada penelitian ini adalah batang pisang yang telah dibuang pada saat pemanenan buah pisang. Kemudian batang pisang dikumpulkan, dibersihkan, dan dipotong dengan ukuran acak, kemudian, batang pisang dikeringkan di bawah sinar matahari. Pengeringan ini bertujuan untuk mengurangi kadar air batang pisang. Penentuan kadar air dilakukan dengan cara mengambil sebagian kecil sampel secara random lalu dipanaskan didalam oven padasuhu $105{ }^{0} \mathrm{C}$ hingga beratnya konstan.

\section{2) Prosedur pembuatan pulp}

Batang pisang yang telah dipersiapkan kemudian dimasak dalam larutan $\mathrm{CH}_{3} \mathrm{COOH}$ pada konsentrasi bervariasi $(70 \%, 80 \%, 90 \% \mathrm{v} / \mathrm{v})$, dengan perbandingan nisbah cairan-padatan 20:1 dan ditambahkan katalis $\mathrm{H}_{2} \mathrm{SO}_{4}$ dengan konsentrasi $0,6 \% \mathrm{v} / \mathrm{v}$, dimasak pada suhu didih normal selama 1 jam, 2 jam, dan 3 jam. Setelah waktu pemasakan tercapai, larutan dan pulp dipisahkan dengan penyaringan. Pulp yang didapat dicuci dengan air sampai sisa air cucian pulp bening. Pulp yang telah dicuci dikeringkan di udara terbuka. Selanjutnya ditimbang dan diuji kadar ligninnya. Pengujian dilakukan dengan konsentrasi katalis $\mathrm{H}_{2} \mathrm{SO}_{4} \quad 0,6 \%$-berat, konsentrasi larutan pemasak $\left(\mathrm{CH}_{3} \mathrm{COOH}\right)$ adalah $(70 \%$, $80 \%, 90 \% \mathrm{v} / \mathrm{v})$ dan lama pemasaknya (1 jam, 2 jam, 3 jam). Cara pengujian kadar lignin

Pengujian kadar lignin pulp dilakukan dengan metode SII 0528-81.

Cara uji:

a) Pulp sebanyak 1 gram dimasukkan kedalam gelas piala $100 \mathrm{ml}$, kemudian ditambahkan asam sulfat $72 \%$ sebanyak $15 \mathrm{ml}$, penambahan dilakukan perlahan- 
lahan dalam bak perendaman dan maserasi selama 2-3 menit.

b) Setelah terdispersi sempurna, ditutup dengan kaca arloji dan dibiarkan dalam bak perendaman selama 2 jam.

c) Erlenmeyer $1000 \mathrm{ml}$ diisi dengan air sebanyak 300-400 ml dan pulp dari gelas piala dimasukkan secara kuantitatif, kemudian diencerkan dengan air sampai volume $575 \mathrm{ml}$ sehingga konsentrasi asam sulfat $3 \%$.

d) Larutan dipanaskan sampai mendidih dan dibiarkan selama 4 jam dengan api kecil dengan menggunakan pendingin balik.

e) Larutan didinginkan diudara terbuka dan dibiarkan sampai lignin mengendap sempurna.

f) Endapan lignin disaring dengan kertas saring lalu dicuci dengan air panas, selanjutnya dikeringkan dalam ovenpadasuhu $105^{\circ} \mathrm{C}$ sampai beratnya konstan.

\section{3) Analisis padatan}

Analisis padatan dilakukan dengan cara gravimetri, yaitu didasarkan perbedaan berat untuk mengetahui perolehan pulp dan kadar selulosa dan lignin dalam pulp.

a) Penentuan perolehan pulp

Pulp yang telah dikeringkan diudara terbuka ditimbang dan ditentukan kadar airnya dengan cara mengeringkan pulp dalam oven sampai beratnya konstan.

$$
\% \text { Perolehan pulp }=\frac{\text { Berat pulp kering }}{\text { Berat biomassa awal }} \times 100 \%
$$

b) Penentuan kadar lignin selulosa

Penentuan kadar lignin pulp dilakukan dengan metoda pengujian

$$
\begin{aligned}
& \% \text { Lignin pulp }=\frac{\text { Berat endapan lignin }}{\text { Berat pulp kering }} \times 100 \% \\
& \% \text { Selulosa pulp }=\frac{\text { Berat pulp kering }- \text { berat lignin }}{\text { Berat pulp kering }} \times 100 \%
\end{aligned}
$$

\section{4) Teknik kuisioner}

Teknik kuisioner yaitu suatu cara untuk memperoleh data dengan menyebarkan angket kepada responden secara tertulis, yang berkaitan dengan judul penelitian, yang kemudian dijawab secara tertulis pula oleh responden, dimana respondennya adalah siswa kelas XI IPA 4 Sekolah Menengah Atas Negeri 1 Tembilahan.

\section{5) Teknik Analisa Data}

Data hasil yang diambil dari penelitian ini adalah yield ( perolehan pulp, kadar lignin pulp dan kadar selulosa pulp). Data yang dihasilkan diplotkan dalam grafik terhadap variabel proses (waktu pemasakan dan konsentrasi larutan pemasak) untuk melihat pengaruh variabel proses tersebut terhadap yield pulp, kadar lignin pulp dan kadar selulosa pulp.

Kemudian teknik analisis data kuisioner pada penelitian ini menggunakan analisis deskriptif kualitatif, yang dipertegas dengan persentase, apabila data telah terkumpul maka akan diklasifikasikan menjadi 2 kelompok yaitu kualitatif, dan kuantitatif, dengan menggunakan rumus:

$$
P=\frac{F}{N} \times 100
$$

Keterangan:

$\mathrm{F}=$ Frekuensi yang sedang dicari persentasenya

$\mathrm{N}=$ Number Of Cass (jumlah frekuensi/banyaknya individu)

$\mathrm{P}=$ Angka persentase

$100 \%=$ Bilangan Tetap, [4].

Adapun kesimpulan dari hasil penelitian dibuat dalam bentuk kalimat dan persentase tersebut diklasifikasikan ke dalam penggolongan sebagai berikut:
1. $81 \%-100 \%$
$=$ Sangat Baik
2. $61 \%-80 \%$
$=$ Baik
3. $41 \%-60 \%$
$=$ Cukup Baik
4. $21 \%-40 \%$
$=$ Kurang Baik
5. $0 \%-20 \%$
$=$ Tidak Baik,[5].

\section{HASIL DAN PEMBAHASAN}

Pembuatan pulp ini dilakukan dengan pemisahan komponen utama penyusun biomassa tersebut, yakni, selulosa, hemiselulosa dan lignin. Pemisahan dilakukan dengan menggunakan pelarut asam asetat. Pemisahan ini didasarkan pada 
sifat fisika dan kimia ketiga komponen utama penyusun biomassa. Penelitian pembuatan pulp batang pisang dengan proses acetosolv dilakukan dalam sistem batch. Pada penelitian ini dilakukan konsentrasi katalis $0,6 \% \mathrm{v} / \mathrm{v}$ dan nisbah cairan padatan 20:1 ( gr/ml) dengan variasi konsentrasi larutan pemasak $(70 \% \mathrm{v} / \mathrm{v}, 80 \%$ $\mathrm{v} / \mathrm{v}, 90 \% \mathrm{v} / \mathrm{v})$ dan waktu pemasakan (1 jam, 2 jam, 3 jam).

Penetrasi merupakan tahap awal pada proses pemasakan pulp, yaitu peristiwa masuknya larutan pemasak ke dalam poripori bahan. Penetrasi ditandai dengan terendamnya seluruh bahan didalam larutan pemasak, atau semua bahan yang dimasak tidak ada yang mengapung. Waktu pemasakan dihitung mulai dari larutan pemasak telah mencapai titik didihnya hingga waktu yang telah ditentukan. Setelah waktu pemasakan tercapai pemasakan dihentikan dengan diangkat erlenmeyer dari pemanas dan direndam ke dalam air selama \pm 15 menit dengan tujuan pendinginan. Pada proses pemasakan terjadi peristiwa delignifikasi dan degradasi polisakarida, dimana pada reaksi delignifikasi terjadi pemutusan ikatan-ikatan lignin dari senyawa-senyawa lain. Kandungan lignin dalam pulp akan semakin berkurang dan perolehan pulp akan semakin rendah, sedangkan degradasi polisakarida adalah polisakarida yang kembali kebentuk monomer-monomernya, [6].

Pada akhir pemasakan diperoleh pulp dan lindi hitam (black liquor). Padatan pulp disaring untuk memisahkan dari lindi hitam. Lindi hitam terdiri dari sisa-sisa bahan kimia, lignin dan karbohidrat yang terlarut dalam larutan pemasak. Setelah pulp dipisahkan dari lindi hitam, pulp dicuci menggunakan air bersih yang mengalir untuk membersihkan pulp dari lindi hitam. Pada proses pencucian pulp batang pisang masih menggunakan penyaring yang sama dengan penyaring lindi hitam. Penyaring masih digunakan untuk memudahkan proses pencucian. Pulp dicuci hingga tidak ada lagi lindi hitam yang masih melekat pada pulp dengan indikasi air sisa pencuci bewarna sama dengan air pencuci.

Untuk menentukan kualitas pulp batang pisang dilakukan analisa pulp yaitu yield pulp, kadar lignin pulp dan selulosa pulp yang dilakukan secara gravimetri. Yield adalah perbandingan berat pulp kering dengan berat bahan baku kering, sedangkan analisa kadar lignin merupakan analisa kadar lignin yang masih terdapat didalam pulp menggunakan prinsip melarutkan selulosa dan hemiselulosa dalam pelarut asam mineral $\mathrm{H}_{2} \mathrm{SO}_{4}$. Secara umum perolehan yield berkisar antara 50,64 - 57,13\%, dan untuk kadar lignin berkisar antara 12,5 $19,42 \%$.

Dari hasil penelitian yang telah dilakukan kondisi terbaik yaitu pulp dengan kadar selulosa tinggi dan lignin yang rendah diperoleh pada konsentrasi pemasak 90\% $\mathrm{v} / \mathrm{v}$ dan waktu pemasakan $3 \mathrm{jam}$. Secara umum pemakaian konsentrasi pemasak yang lebih besar dan waktu pemasakan yang lama menghasilkan pulp dengan kadar selulosa tinggi dan lignin yang relatif rendah, [7]. Semakin tinggi konsentrasi dan semakin lama waktu pemasakan mengakibatkan mol asam asetat yang bereaksi dengan lignin menjadi semakin besar sehingga lignin yang dapat didegradasi menjadi lebih banyak. Dengan lignin yang semakin banyak didegradasi menyebabkan sisa hasil reaksi menjadi lebih kecil. Hasil reaksi yang semakin kecil mengakibatkan yield pulp yang didapatkan menjadi lebih rendah. Semakin tingginya konsentrasi asam asetat yang digunakan, menyebabkan lebih banyak asam asetat yang dapat mengikat lignin. Degradasi dari lignin menyebabkan selulosa yang sebelumnya terikat oleh lignin akan terlepas dari lignin sehingga didapat kandungan pulp dengan kadar selulosa yang lebih tinggi, [8]. 


\section{Pengaruh Kondisi Proses}

\section{1) Pengaruh Kondisi Proses Larutan Pemasak dan Waktu Pemasakan Terhadap Yield Pulp}

Dalam penelitian ini larutan pemasak yang digunakan adalah $\mathrm{CH}_{3} \mathrm{COOH}$ dengan konsentrasi $70 \% \mathrm{v} / \mathrm{v}, 80 \% \mathrm{v} / \mathrm{v}$ dan $90 \% \mathrm{v} / \mathrm{v}$. Variasi konsentrasi pemasak dan waktu pemasakan memberikan pengaruh terhadap yield pulp batang pisang. Gambar I. memperlihatkan pengaruh variasi konsentrasi pemasak dan waktu pemasakan terhadap yield pulp batang pisang.

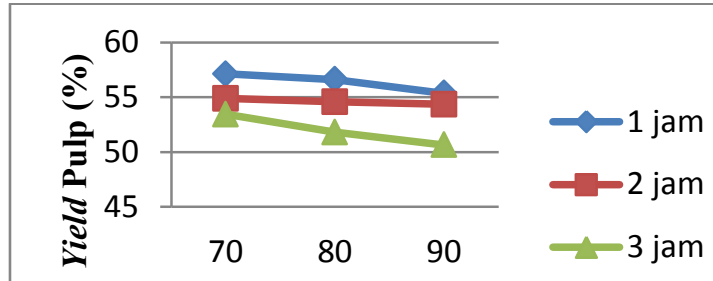

Konsentrasi larutan pemasak ( $\%$ v/v)

Gambar 1. Yield pulp terhadap variasi konsentrasi larutan pemasak dan waktu pemasakan.

Peningkatan konsentrasi pemasak untuk berbagai proses cenderung menurunkan yield pulp. Pada konsentrasi pemasak 70\%$80 \% \mathrm{v} / \mathrm{v}$ dengan waktu pemasakan 1 jam terjadi penurunan pulp yaitu dari $57,13 \%$ menjadi $56,61 \%$. Peningkatan konsentrasi pemasak dari $70 \%-80 \%$ v/v pada waktu pemasakan 2 jam menyebabkan perolehan pulp menurun yaitu dari $54,88 \%$ menjadi $54,58 \%$. Peningkatan konsentrasi pemasak dari $70 \%-80 \%$ v/v pada waktu pemasakan 3 juga mengalami penurunan perolehan yield pulp yaitu dari 53,44\% menjadi 51,81\%.

Selain konsentrasi pemasak, variabel proses yang dipelajari yang dapat mempengaruhi yield pulp batang pisang adalah waktu pemasakan. Peningkatan waktu pemasakan juga cendrung menurunkan yield pulp. Pada waktu pemasakan 1 jam ke 2 jam, dan 3 jam konsentrasi pemasak $70 \% \quad \mathrm{v} / \mathrm{v}$ terjadi penurunan pulp dari $57,13 \%, 54,88 \%$ dan $53,44 \%$, dimana penurunan terjadi sebesar $3,69 \%$. Yield pulp cendrung menurun untuk waktu pemasakan 1 jam sampai 3 jam pada kenaikan konsentrasi $70 \%$ v/v sampai $90 \%$ $\mathrm{v} / \mathrm{v}$. Penurunan pulp juga disebabkan oleh kenaikan laju delignifikasi yang dibantu dengan adanya katalis. Secara umum pada penelitian pembuatan pulp batang pisang ini, peningkatan konsentrasi larutan pemasak dan waktu pemasakan menyebabkan yield pulp cendrung menurun. Penurunan yield terjadi karena larutan pemasak dapat mendegradasi lignin dalam bahan baku. Secara umum peningkatan kondisi proses dapat menyebabkan penurunan yield dan kadar lignin pulp, [9]. Dengan berkurangnya kandungan lignin maka perolehan pulp semakin berkurang.

Yield pulp menurut standar industri pulp berkisar antara 40-55\%, [10]. Jika dilihat dari yield pulp yang dihasilkan, maka pulp batang pisang yang dihasilkan pada penelitian ini baik untuk dijadikan sebagai bahan baku alternatif untuk industri pulp. Pulp dengan kualitas yang memadai untuk dijadikan kertas dapat dilihat dari perbandingan yield terhadap kadar lignin pulp dan kadar selulosa pulp pada bahan baku.

\section{2) Pengaruh Kondisi Proses Larutan Pemasak dan Waktu Pemasakan Terhadap Kadar Lignin Pulp}

Variasi konsentrasi pemasak dan waktu pemasakan juga memberikan pengaruh terhadap kadar lignin pulp batang pisang. Pengaruh konsentrasi pemasak dan waktu pemasakan terhadap kadar lignin pulp batang pisang diperlihatkan pada gambar 2 .

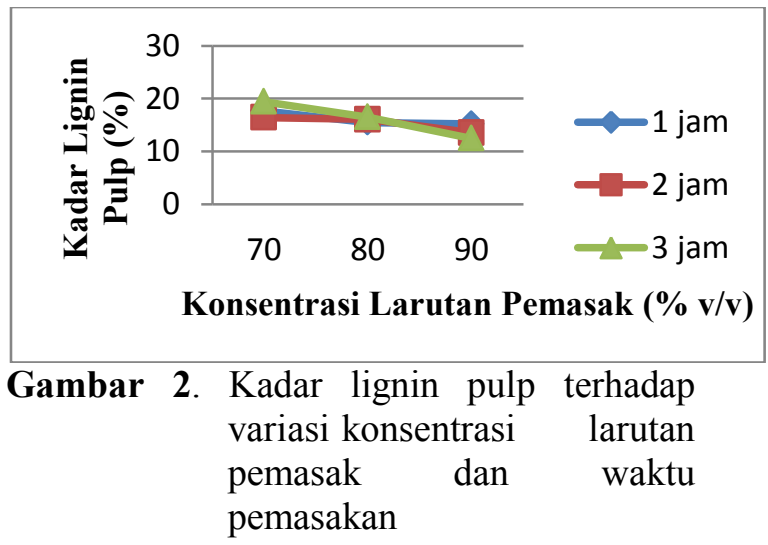


Pada peningkatan konsentrasi pemasak $70 \%$ v/v ke $80 \%$ v/v dengan waktu pemasakan 1 jam terjadi penurunan kadar lignin pulp yaitu dari $17,70 \%$ menjadi 15,49\%. Peningkatan konsentrasi pemasak $70 \%$ ke $80 \%$ v/v pada waktu pemasakan 2 jam juga terjadi penurunan kadar lignin yaitu dari $16,42 \%$ menjadi $16,08 \%$. Pada konsentrasi pemasak $70 \% \mathrm{ke} 80 \% \mathrm{v} / \mathrm{v}$ pada waktu pemasakan 3 jam juga terjadi penurunan kadar lignin dari 19,42\% menjadi $16,53 \%$.

Perolehan kadar lignin pulp meningkat pada konsentrasi $70 \% \mathrm{v} / \mathrm{v}$ dengan waktu pemasakan 2-3 jam terjadi kenaikan yaitu dari $16,42 \%$ menjadi $19,42 \%$. Kenaikan kadar lignin pulp tersebut mengindikasi adanya hemiselulosa yang terlarut bersama lignin pada proses pembuatan pulp, [11] Selain konsentrasi pemasak, waktu pemasakan juga dapat mempengaruhi perolehan kadar lignin pulp.

Pada waktu pemasakan 1 jam -3 jam dengan konsentrasi pemasak $90 \% \mathrm{v} / \mathrm{v}$ terjadi penurunan kadar lignin pulp yaitu dari $15,23 \%, \quad 13,54 \%$ dan $12,5 \%$ dimana penurunan terjadi sebesar $2,73 \%$. Pada rentang waktu 1 jam - 3 jam dengan konsentrasi pemasak $80 \% \quad \mathrm{v} / \mathrm{v}$ terjadi kenaikan kadar lignin pulp yaitu dari $15,49 \%, 16,08 \%$ dan $16,53 \%$ dimana kadar lignin pulp mengalami kenaikan sebesar $1,04 \%$. Kadar lignin pulp cendrung lebih sedikit pada waktu pemasakan lebih lama. Secara umum pemakaian konsentrasi pemasak yang lebih besar menghasilkan pulp dengan kadar lignin yang relatif rendah.

Pada proses acetosolv umumnya degradasi lignin tidak terlalu besar. Meningkatnya jumlah larutan pemasak berarti bertambahnya ion $\mathrm{H}^{+}$yang berperan dalam pemutusan ikatan lignin. Reaksi ini terjadi dengan cara mengubah polimer lignin menjadi monomer-monomer penyusunnya dan melarutkannya kedalam cairan pemasak. Semakin lama waktu pemasakan menyebabkan semakin sempurna larutan pemasak memenuhi rongga-rongga pada bahan baku, sehingga degradasi lignin lebih banyak terjadi.

\section{3) Pengaruh Kondisi Proses Larutan Pemasak dan Waktu Pemasakan Terhadap Kadar Selulosa Pulp}

Variasi konsentrasi pemasak dan waktu pemasakan dapat memberikan pengaruh terhadap perolehan kadar selulosa pulp batang pisang. Pengaruh variasi konsentrasi pemasak dan waktu pemasakan terhadap kadar selulosa pulp diperlihatkan pada gambar 3 .

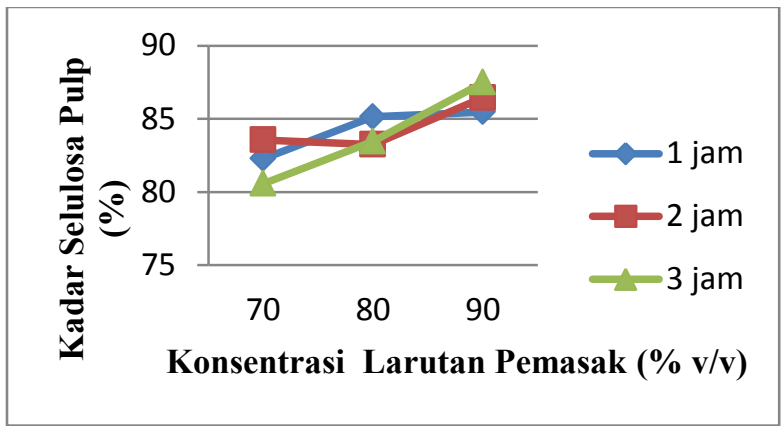

Gambar 3. Kadar Selulosa pulp terhadap variasi konsentrasi larutan pemasak dan waktu pemasakan.

Pada konsentrasi pemasak 70\%-80\% $\mathrm{v} / \mathrm{v}$ dengan waktu pemasakan 1 jam terjadi peningkatan kadar selulosa pulp yaitu dari $82,28 \%$ menjadi $85,13 \%$. Peningkatan kadar selulosa pulp juga terjadi kenaikan pada konsentrasi $70 \%-90 \% \mathrm{v} / \mathrm{v}$ yaitu dari $80,57 \%$ menjadi $87,49 \%$ dengan waktu pemasakan 3 jam. Sedangkan pada konsentrasi pemasakan $70 \%-80 \%$ v/v dengan waktu pemasakan 2 jam terjadi penurunan kadar selulosa pulp, yaitu dari 83,56\% menjadi 83,24\%. Penurunan kadar selulosa pulp disebabkan karena delignifikasi dan degradasi selulosa tidak dapat dihindari. Kadar selulosa pulp cendrung naik dengan meningkatnya waktu pemasakan. Peningkatan kadar selulosa di dalam pulp disebabkan oleh lamanya molekul-molekul larutan pemasak bereaksi dengan senyawa lignoselulosa, sehingga ikatan lignin dan hemiselulosa terputus dari ikatan selulosa, akhirnya meningkatkan kandungan selulosa didalam pulp, [12]. 
a. Data Tentang Implementasi Pengetahuan Siswa Sekolah Menengah Atas Negeri 1 Tembilahan Terhadap Pemanfaatan Batang Pisang Dalam Pembuatan Pulp.

Angket yang disebarkan kepada responden diharapkan dapat memberikan jawaban tentang Implementasi Pengetahuan Siswa Disekolah Menengah Atas Negeri 1 Tembilahan terhadap pemanfaatan batang pisang dalam pembuatan pulp. Angket yang digunakan pada penelitian ini adalah angket tertutup atau terstruktur yaitu angket yang disusun dengan pilihan jawaban yang telah tersedia. Angket ini menggunakan alternatif jawaban sangat tidak setuju dengan skor 1, tidak setuju dengan skor 2 , ragu-ragu dengan skor 3 , setuju dengan skor 4 dan sangat setuju dengan skor 5. Pernyataan-pernyataan angket yang diberikan terdiri dari 7 item.

Setelah hasil didapatkan, maka dapat diberi kesimpulan bahwa implementasi pengetahuan siswa di Sekolah Menengah Atas Negeri 1 Tembilahan terhadap pemanfaatan batang pisang dalam pembutan pulp dikategorikan "Sangat Baik" karena hasil akhir dari pengolahan data dari lapangan menunjukkan persentasinya diperoleh $86,78 \%$ yang terletak di rentang $81 \%-100 \%$, persentasi ini dikategorikan "Sangat Baik".

\section{SIMPULAN}

a. Penggunaan konsentrasi larutan pemasak $\left(\mathrm{CH}_{3} \mathrm{COOH}\right)$ dan variasi waktu pemasakan pada pembuatan pulp batang pisang dengan metode acetosolv akan memberikan perolehan pulp, kadar lignin dan kadar selulosa pulp yang bervariasi.

b. Rata-rata yield pulp yang dihasilkan pada penelitian ini yaitu $54,13 \%$. Sedangkan rata-rata kadar lignin yang diperoleh sebesar $15,88 \%$ dan rata-rata kadar selulosa yang dihasilkan adalah $84,18 \%$. Pulp yang terbaik diperoleh pada konsentrasi larutan pemasak $90 \% \mathrm{v} / \mathrm{v}$ dan waktu pemasakan 3 jam, menghasilkan yield pulp terendah, yaitu 50,64\% dengan kadar lignin pulp rendah yaitu $12,5 \%$ dan kadar selulosa tinggi yaitu $87,49 \%$.

c. Implementasi pengetahuan siswa di Sekolah Menengah Atas Negeri 1 Tembilahan terhadap pemanfaatan batang pisang dalam pembuatan pulp dikategorikan "Sangat Baik" karena hasil akhir menunjukkan persentase yang diperoleh $86,78 \%$ yang terletak direntang $81 \%-100 \%$, persentase ini berada pada kategori "Sangat Baik"

\section{REFERENSI}

[1], [8] Wibisono, Ivan, et all. 2011. Pembuatan Pulp Dari Alang-Alang. Jurnal Teknik Kimia Universitas Katolik Widya Mandala Surabaya. Volume 10. No 1. 11-20.

[2] Cahyono, Bambang. 1995. Pisang Budidaya dan Analisis Usahatani. Kanisius.

[3] Syafii, Wasrin. Daur Ulang Bahan Kimia Pada Proses Organosolv Beberapa Jenis Kayu Daun Lebar Cepat Tumbuh. Jurnal teknik industri. Volume 10. No 3. 93-98.

[5] Riduwan. 2005. Skala Pengukuran Variabel-Variabel Penelitian. Bandung: Al-Fabeta.

[6], [12] Jalaluddin dan samsul Rizal. 2005. Pembuatan pulp dari jerami padi dengan menggunakan natrium hidroksida. Jurnal sistem teknik industri. Vol 6. No 5. November.

[7] Jin, Yungcan, Z.Z.LEE dan Jahan M Sarwan. (30:2006). Organic acid Pulping Of Rice Straw, I: Cooking.

[9], [11] Maulvi, Sani Ikmal, Zulfansyah, Muhammad Iwan Fermi. 2011. Pembuatan Pulp Semi Mekanis dari Batang Jagung dengan Ekstrak Abu Tandan Kosong Sawit. Jurnal Teknik KimiaUniversitas Riau. Pekanbaru.

[10]Hanika Puspitasari, Shelviana, Zulfansyah, Hari Rionaldo. Delignifikasi Batang Jagung dengan 
Proses Organosolv Menggunakan

Pelarut Asam Formiat. Jurnal Teknik

Kimia Universitas Riau. 